\title{
BEES OF THE GENUS HALICTUS FROM MIAMI, FLORIDA
}

\author{
By S. Graenicher, \\ South Miami, Fla.
}

The following two species belong to the group of Chloralictus with punctured tegulæ.

\section{H. (Chloralictus) marinus Grawford.}

Described from the female $(1,99)$. The punctured tegulæ, which are pointed posteriorly, place it next to tegulariformis Crawford (New Mexico) in the Sandhouse key to females $(3,1)$, but in the latter species the disk of the propodeum is granular while in marinus it has longitudinal rugæ running the length of the disk.

Male. Entire face up to the median ocellus covered with a dense short white pubescence. Head behind the eyes, sides of meso- and metathorax, scutellum, femora and sides of abdomen with long white hairs. Mesonotum and abdominal segments one to four above, shining and nearly bare. Facial quadrangle much narrower and longer than in the female. Clypeus produced half its length beyond the eyes. Antennæ dark above, light ferruginous underneath from second joint on. Tegulæ bare, shining, the punctures more plainly visible than in the female, Abdomen slender, with hardly a trace of testaceous coloration along the apical margins of the segments. Knees and tips of tibiæ narrowly testaceous, tarsi nearly white.

This species occurs at Miami Beach (across Biscayne Bay from Miami), where I have collected both males and females in January, July, August and December, at the flowers of the sunflower Helianthus debilis.1 Quite recently (April 23, 1927) five males were found at Golden Beach (on the Atlantic Ocean north of Miami), visiting the flowers of Alternanthera floridana; also, one male and two females (April 29) on the sand dunes along the

"Nomenclature according to Small's "Flora of Miami" and the same author's "Flora of the Southeastern United States." 
Atlantic Ocean north of Cape Florida (on Biscayne Key, across the Bay southeast of Miami). These, too, were taken on the flowers of Alternanthera floridana. In all three localities they were encountered on the upper beach, a short distance from the ocean, and this agrees entirely with what Viereck and Crawford observed in New Jersey and Virginia. According to the former's statement (cited by Crawford, 1), the specimens were swept at Ocean City, N. J. (type locality) from plants "growing along the strand just within the beach, and constituting the first zone of plant life from the ocean." Crawford $(2,580)$ came across this species at Virginia Beach, Va. "on grasses on the beach just above high tide limit." In view of these facts it is safe to assume that $H$. marinus is an inhabitant of the upper sandy beaches along the entire Atlantic coast from south Florida to New Jersey.

\section{Halictus (Chloralictus) lepidii, n. sp.}

Female. Length about $4.5 \mathrm{~mm}$. Head and thorax dark green, abdomen dark brown. Antennæ dark with testaceous tips. Facial quadrangle longer than broad, plainly narrowed below. Clypeus produced more than half its length beyond the eyes. Punctures on front and sides of face small and close together, those on supraclypeal area larger and farther apart; on the clypeus they become much coarser towards the base, which is dark purple. Sides of face with short sparse whitish pubescence. Mesonotum with fine pucntures, close on top, more scattered along the sides. Metathorax coarsely punctured. Scutellum much more finely and closely punctured than the adjoining portion of the mesonotum. Propodeum truncate with smooth rounded angles. Disk with inconspicuous short plicx. No rim. Abdomen ovate. First two segments smooth and shining with whitish hairs on the sides. Remaining segments covered with short, sparse pubescence. Extreme apical margin of each segment faintly testaceous. Front wing about $3 \mathrm{~mm}$. long, somewhat dusky. Tegulæ black and shining, lighter on top, with inconspicuous sparse punctures. Veins dark, stigma dark testaceous. Second submarginal cell about as long as 
high, much narrowed above. Third submarginal over one and one-half times as long as the second on the marginal vein. Legs dark, clothed like the rest of the body with pale pubescence.:

Male. Differs from the female as follows: Mesothorax of a lighter green and more shining. Abdomen black, long, very slender, smooth and shining above along its entire length. Facial quadrangle much narrower below. Face below antennæ with a dense covering of short white pubescence. Antennæ below testaceous from third joint on. Third antennal joint a little longer than second. Tegulæ more closely punctured. Ridges on disk of propodeum shorter and less distinct. Wings clearer, stigma and veins darker, the latter more sharply defined. Second submarginal cell shorter.

Described from twelve males and fourteen females captured at South Miami, Miami, Cape Florida (across the bay southeast of Miami), Golden Beach and Hollywood (both north of Miami). They were visitors to the flowers of Lepidium virginicum, Warea Carteri, Galactia pinetorum, Sida carpinifolia, Chrysopsis Tracyi and Alternanthera floridana. Type and allotype in the author's collection.

In the Sandhouse Key to females this species runs next to ellisioe Sandhouse from Massachusetts $(3,11)$, but differs mainly in the following characters: antennæ testaceous at the tips, scutellum closely punctured all over (no smooth spots on the disk), tegulæ slightly testaceous above, disk of propodeum with ridges on basal half.

\section{H. (Chloralictus) nymphalis F. Smith}

Described from St. John's Bluff, East Florida $(4,68$.) There are in my collection specimens from Miami, South Miami and Hollywood (north of Miami) and also one from Jacksonville (near the type locality) captured September 25, 1925. . At South Miami it flies with slight interruption throughout most of the year, but seems to be present in greater numbers during the fall months. It has been taken at the flowers of Opuntia austrina, Croton linearis, Galactia pinetorum, Lepidium virginicum, Warea Carteri, Chrysopsis Tracyi and Portulaca oleracea. It prefers 
sandy soil, and will probably be found in suitable locations along the entire East Coast of Florida.

\section{H. (Chloralictus) longiceps Robertson}

Described from the female $(\mathbf{5}, 272)$. This species is easily recognized on account of its long, narrow head with the strongly produced clypeus, and the swollen upper portion of its occiput.

Male. Face narrower and longer than in the female, covered to a little above the antennæ with short loose pubescence. Face above the antennæ, and vertex with a brassy tinge. Antennæ slightly testaceous underneath from the third joint on. Third antennal joint longer than second, fourth nearly as long as second and third combined. Wing veins darker and more clearly outlined than in the female. Abdomen slender, black and nearly bare except near the tip. Tarsi white, the last joint brownish.

The time of flight of the females covers the entire year. Males and females have been taken at Miami, South Miami and Hollywood at the flowers of Croton linearis, Warea Carteri, Lepidium virginicum, Pycnothymus rigidus, Opuntia austrina, Galactia pinetorum, Laciniaria gracilis, Mikania batatifolia, Chrysopsis Tracyi and Solidago angustifolia.

\section{Halictus (Chloralictus) halophitus n. sp.}

Female. Length $5.5 \mathrm{~mm}$. Head and thorax dark green and shining. Abdomen ovate, dark brown with narrow, hardly perceptible testaceous margins. Dirty-white pubescence of body sparse and short, longer on sides of thorax and femora. Face longer than broad, narrowed considerably below. Clypeus produced nearly its entire length beyond the eyes. Punctures of the face delicate and close together, those of the supra-clypeal area and clypeus coarser and less numerous. Clypeus with a purplish reflection, mandibles reddish beyond the middle. Apical region of antennæ faintly testaceous. Mesonotum finely and closely punctured on a slightly roughened surface. Mesopleuræ coarsely scluptured. Tegulæ shining, light testaceous, rounded in front, nearly straight behind. Front wing about $3.8 \mathrm{~mm}$. long. Wings somewhat dusky, veins dark testaceous, stigma much 
lighter. First submarginal cell nearly as long as second and third together. Second considerably shorter than third, narrowed one-third towards the marginal. Disk of propodeum without a rim, narrowed towards the apex to such an extent as to appear somewhat triangular. Its surface finely granular, with a distinct median ridge, and about 8 lower and much shorter ones on each side. Legs dark, knees and tarsi testaceous. Abdomen shining throughout, especially the first segment, which is smooth. Remaining segments with indistinct scattered punctures.

Male. Inner orbits straighter than in the female, especially above. Face densely covered with a short white pubescence beneath the antennæ and on the sides above. Mandibles slender, very light testaceous, tips blackish. Labrum light testaceous. Antennæ dark on upper surface, reddish underneath from the second joint on. Third joint longer than second. Mesonotum and scutellum shining, nearly bare. Ridges on disk of propodeum more numerous but less prominent than in the female. Knees, tips of tibiæ and tarsi light yellow. Abdomen slender, very shiny with metallic reflections. Apex of first segment convex, forming a distinct depression between it and the second segment.

Described from six males and seven females taken April 20, May 20 and August 15 at Cutler, south of Miami, on the flowers of Bramia Monniera and Sesuvium maritimum. Type and allotype in the author's collection.

The low marshy grounds in this locality border on Biscayne Bay. On account of the influence of high tides and occasional storms which drive the water up over the shores, the soil supports a typical halophytic (salt-loving) plant association, and the two species mentioned above (Bramia and Sesuvium) form low carpet-like patches between the shrubs and small trees inhabiting the dryer portions of the marsh.

This species seems to be most closely related to tropicior Ellis, from Guatemala $(8,219)$, but the female differs from that of tropicior as follows: clypeus produced nearly its entire length beyond the eyes, punctures uf mesonotum closer together (not scattered as in tropicior), abdominal segments with testaceous margins. 
H. (Chloralictus) rhododactylus D. T.(fulvipes F. Smith)

A female captured July 19, 1916 at Homestead (28 miles south of Miami) evidently belongs here. Type locality: St. John's Bluff, East Florida (4, 67). This specimen agrees well with the original description, as also with the notes furnished by Cockerell $(9,351)$, who examined the type in the British $\mathrm{Mu}-$ seum. I have never come across it since, and it seems to be a rare insect in this part of Florida.

\section{H. ligatus Say.}

For this species Robertson has proposed the genus Odontalictus $(7,91)$ on account of the cheek of the female being produced into a tooth. It is by far the most common bee of our surroundings, flying throughout the year, and visiting a great variety of flowers, especially Compositæ. Robertson $(6,322)$ has given a synonomy of this widely distributed and variable species, and pointed out that the specimens from Florida belong to the form described by F. Smith as H. capitosus $(4,67)$.

\section{LITERATURE}

1. J. C. Crawford: Two new Halictus from New Jersey. Ent. News 15, 97-99 (1904)

2. J. C. Crawford: Proc. U. S. Nat. Mus. 48. No. 2087 (1915)

3. G. A. Sandhouse: New N. Am. species of bees belonging to the genus Halictus (Chloralictus). Proc. U. S. Nat. Mus. 65, No. 2532 (1924)

4. F. Smith: Brit. Mus. Cat. Hym. I. (1853)

5. C. Robertson: Am. Naturalist 26 (1892)

6. C. Robertson: N. Am. bees-descriptions and synonyms. Trans. Acad. Sci. St. Louis 7, 315-354 (1897)

7. C. Robertson: Some genera of bees. Ent. News 29, 91-92 (1918)

8. M. D. Ellis: New bees of the genus Halictus from United States, Guatemala and Ecuador. Jour. N. Y. Ent. Soc. 22, 218-223 (1914)

9. T. D. A. Cockerell: Notes on some bees in the British Museum. Trans. Am. Ent. Soc. 30, 309-361 (1915) 

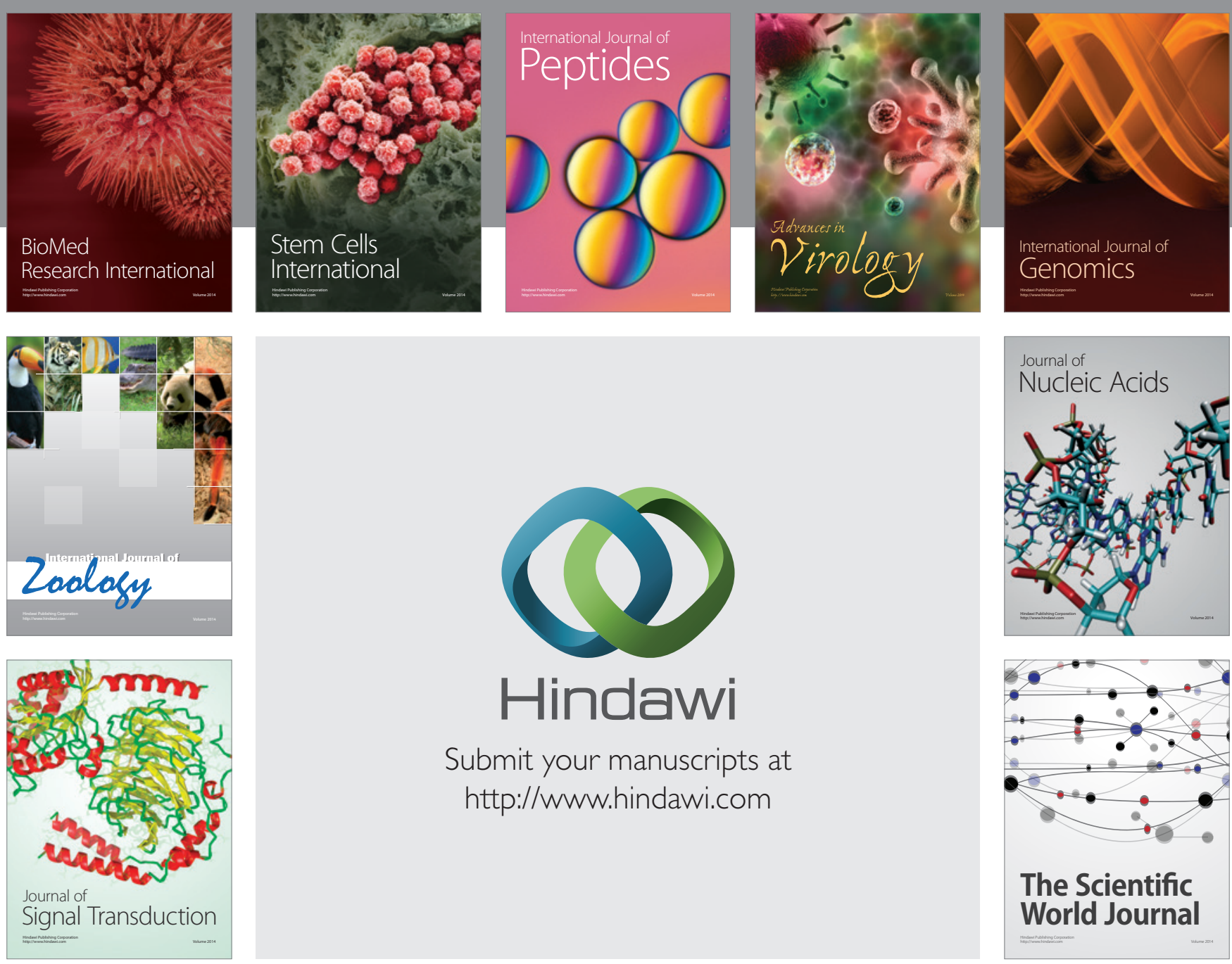

Submit your manuscripts at

http://www.hindawi.com
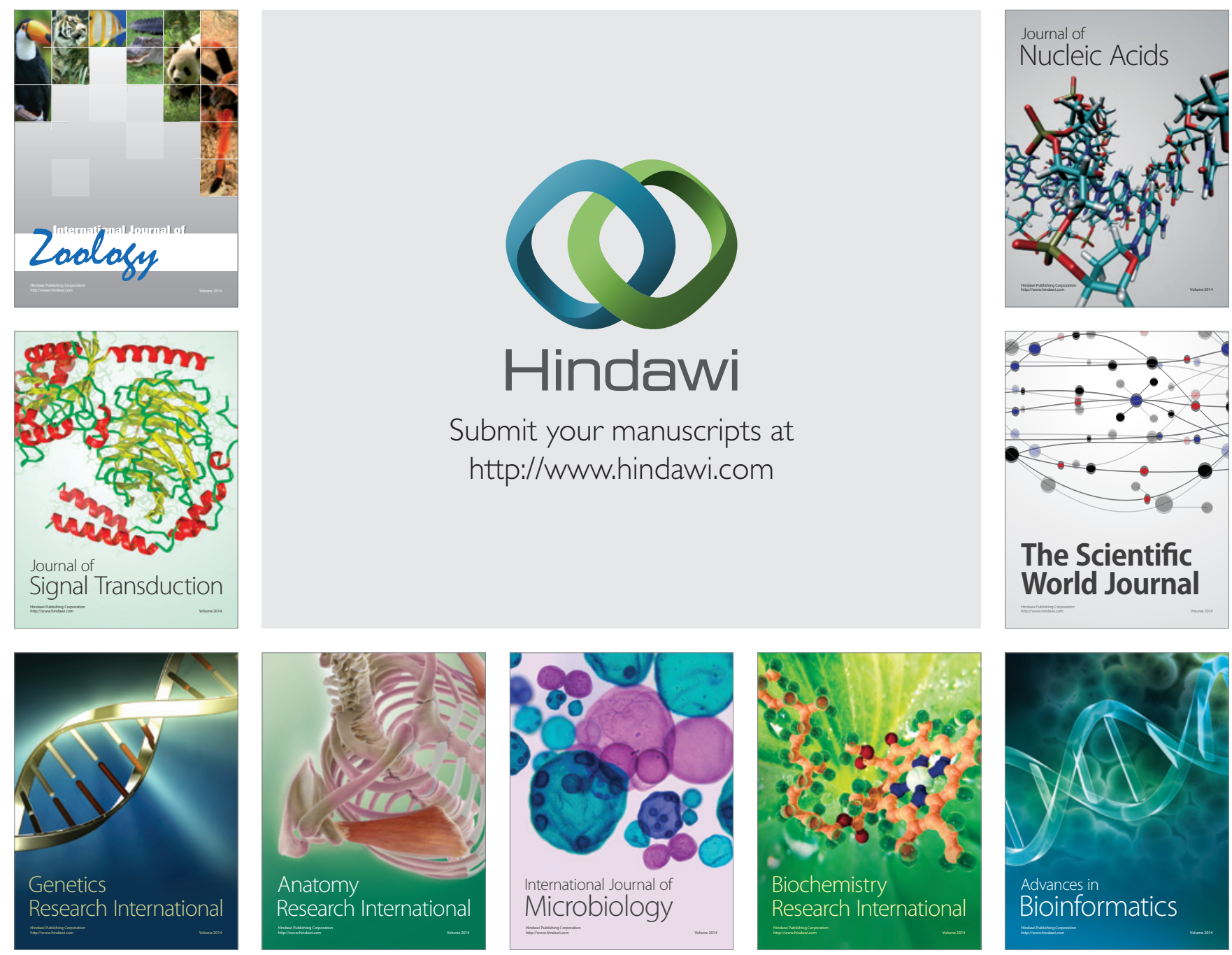

The Scientific World Journal
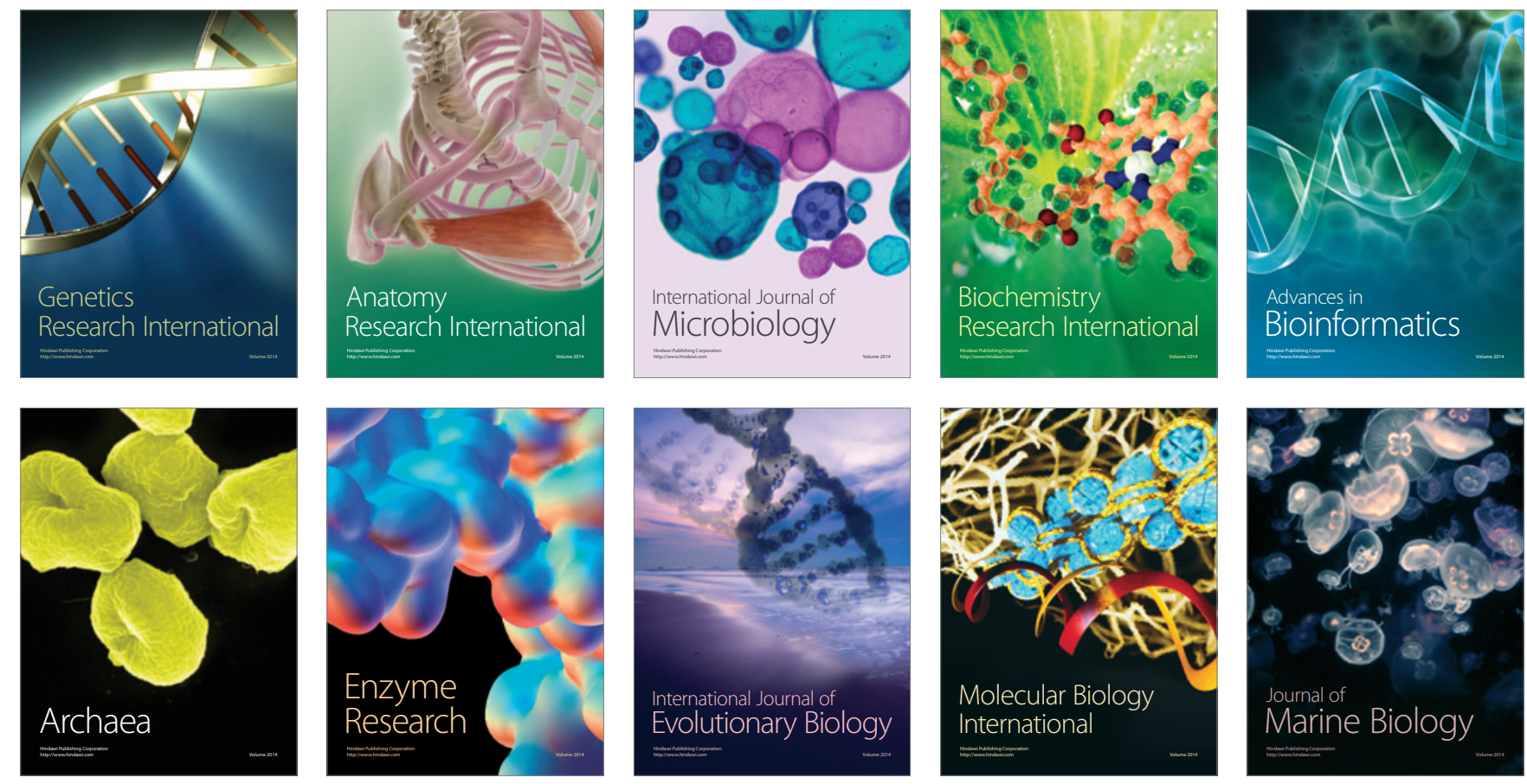